\title{
Atopic dermatitis: allergic dermatitis or neuroimmune dermatitis? ${ }^{*}$
}

\author{
Neide Kalil Gaspar ${ }^{1}$
}

Márcia Kalil Aidé2

DOI: http://dx.doi.org/10.1590/abd1806-4841.20164211

\begin{abstract}
Advances in knowledge of neurocellulars relations have provided new directions in the understanding and treatment of numerous conditions, including atopic dermatitis. It is known that emotional, physical, chemical or biological stimuli can generate more accentuated responses in atopic patients than in non-atopic individuals; however, the complex network of control covered by these influences, especially by neuropeptides and neurotrophins, and their genetic relations, still keep secrets to be revealed. Itching and airway hyperresponsiveness, the main aspects of atopy, are associated with disruption of the neurosensory network activity. Increased epidermal innervation and production of neurotrophins, neuropeptides, cytokines and proteases, in addition to their relations with the sensory receptors in an epidermis with poor lipid mantle, are the aspects currently covered for understanding atopic dermatitis.
\end{abstract}

Keywords: Cytokines; Dermatitis, atopic; Neuropeptides

\section{INTRODUCTION}

Lesion innervation and atopic dermatitis

The neuroendocrine system is present in all organs of the body, from specialized endocrine cells to nerves containing neuropeptides, and the overgrowth of these nerves and their penetration into epidermis are characteristics of atopic dermatitis (AD) (Figure 1). ${ }^{1-6}$ Sensory and autonomic nerve fibers of the skin have trophic and immune modulatory properties and, in this context, the nerves contact keratinocytes directly, regulating the cytokine production. ${ }^{7}$

Physical, chemical, biological or immunological stimuli can release the contents of neuropeptides, which are produced by the neuronal bodies of the posterior cords of the dorsal root and stored locally in vesicles in the skin nerve endings. ${ }^{2,8}$ This skin/nerve communication is bidirectional, since the release of these neuropeptides in the skin, especially of substance $\mathrm{P}(\mathrm{SP})$ and of calcitonin gene-related peptide (CGRP), stimulates the keratinocytes to develop the nerve growth factor (NGF). NGF, in addition to acting autocrinally promoting keratinocytes reproduction, also stimulates, retrogradely, neurons of the posterior cords of dorsal root to produce neuropeptides (Figure 2).
In atopic lesions of experimental animals, the application of anti-NGF antibodies inhibits pruritus and other aspects of $A D$, besides determining the reduction of elongated and proliferated nerve fibers, which penetrate the epidermis. ${ }^{5,6,9}$ This hyperinnervation also decreases with phototherapy and with the application of calcineurin inhibitor, in addition to improving itching and lesional appearance (Figure 3). ${ }^{10-13}$

In AD keratinocytes, semaphorin membrane protein, which has the function of limiting the growth of nerves, is reduced or absent in lesional epidermis in conjunction with the increase of nervous fibers. ${ }^{14}$ Application of semaphorin $3 \mathrm{~A}$ in the skin of atopic animals reduces lesions and itching, as well as the number of inflammatory cells and the presence of nerves (Figure 4). 15,16

Presence of semaphorin in the epidermis returns after phototherapy, in addition to the reduction in the presence of nerves in the skin (Figures 3 and 5A). ${ }^{17}$ This epidermal hyperinnervation is also observed in diseases with chronic itching both in experimental animals and in humans. ${ }^{17}$ In those, the expression of nerve growth factor (NGF) reflects the severity of lesions, the intensity of itching and the validity of the treatment. ${ }^{17,18}$ The presence of this factor is also reduced with PUVA therapy (Figure 5B).

Conflict of Interest: None. 


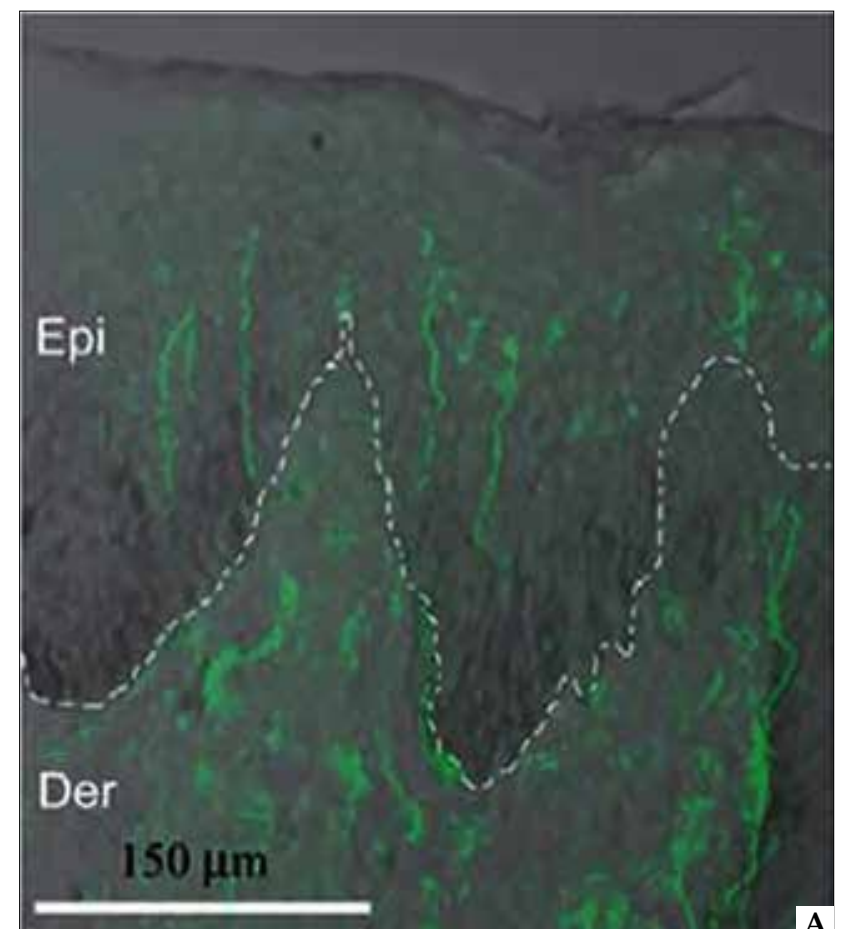

Atopic dermatitis

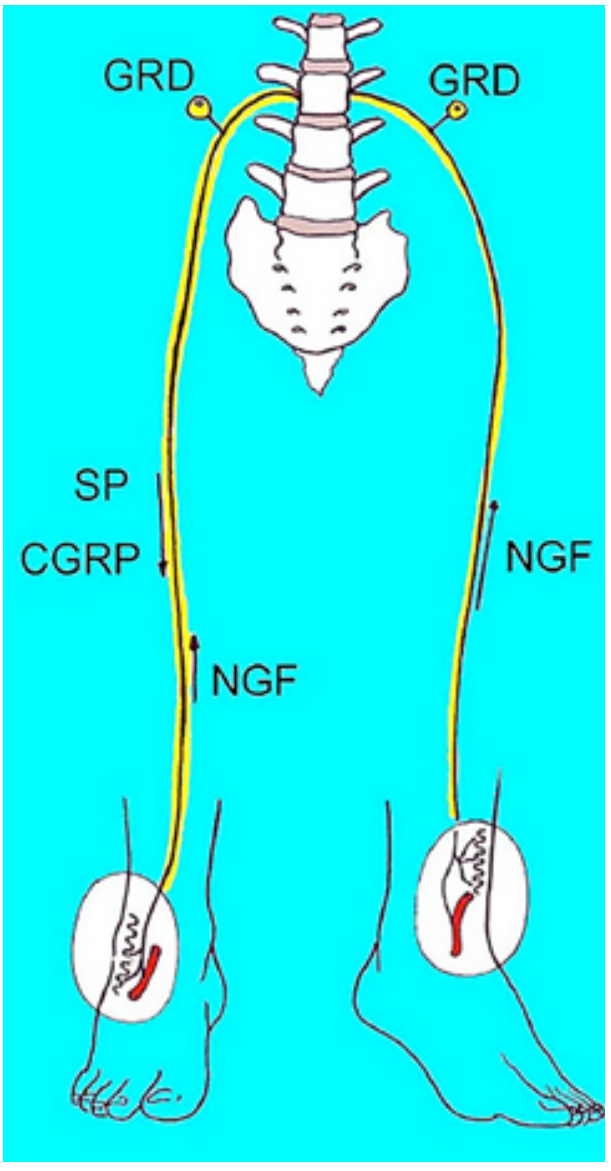

FIGURE 2:

Skin / nerve bidirectional circuit: nerve fibers scheme contacting directly basal keratinocytes. The release of neuropeptides st imula te s the proliferation of basal cells. When they multiply, they develop NGF, which is autocrine for these, and by retrograde pathway, runs through the axons, reaches the neuron bodies and stimulates their tropism and production of neuropeptides

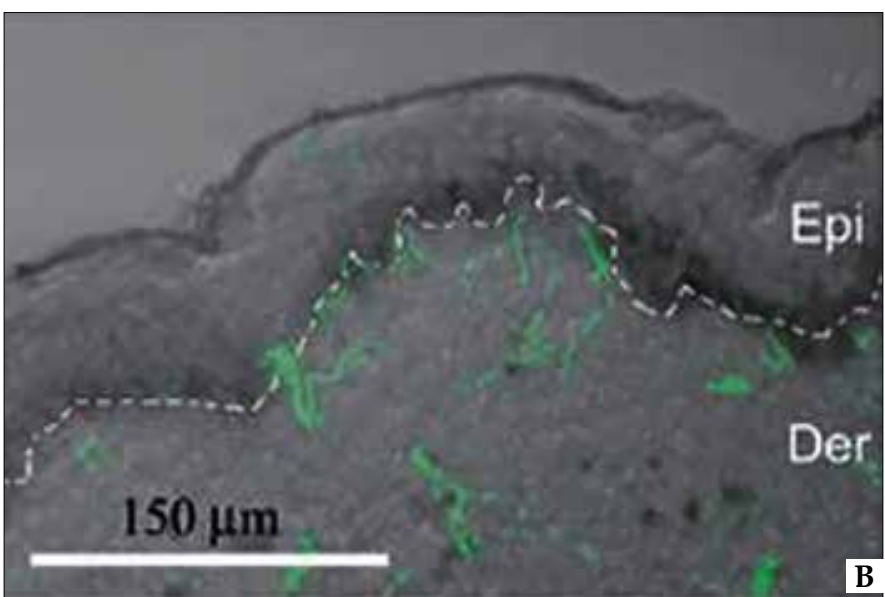

Healthy control

FIGURE 1: Nerves marked in green (PGP 9.5). A: Lesional epidermis: presence of nerves (marked in green with PGP 9.5). Dermoepidermal limit enhanced by adding a discontinued white line. B: Non-lesional epidermis: nerves evidenced only in the dermis

Source: Tominaga et al, $2013 .^{5}$

A

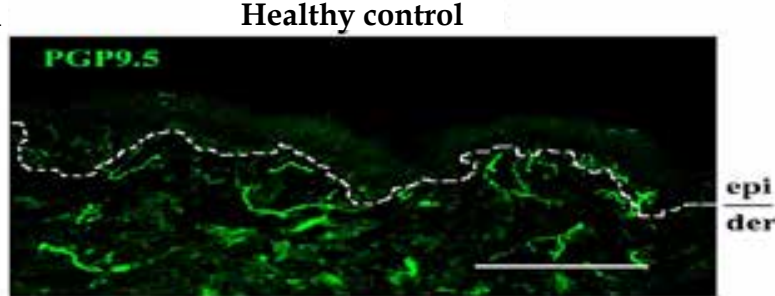

B

Before PUVA

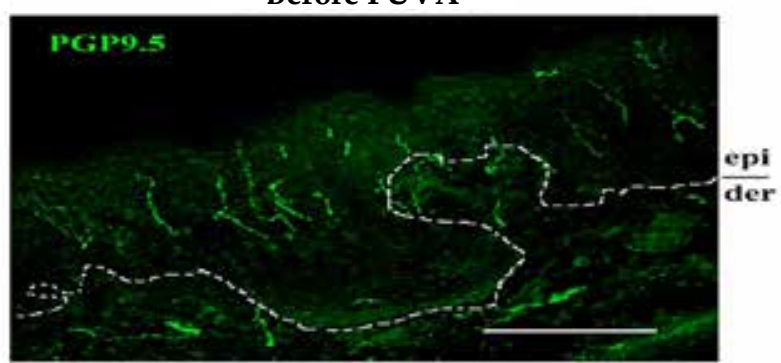

C

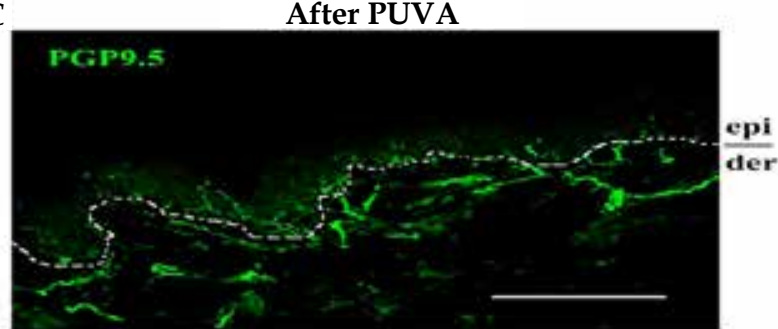

Source: Wallengren J et al, 2013.

FIgURE 3: A: Healthy control. B: Atopic dermatitis: before PUVA. C: Atopic dermatitis: after PUVA 

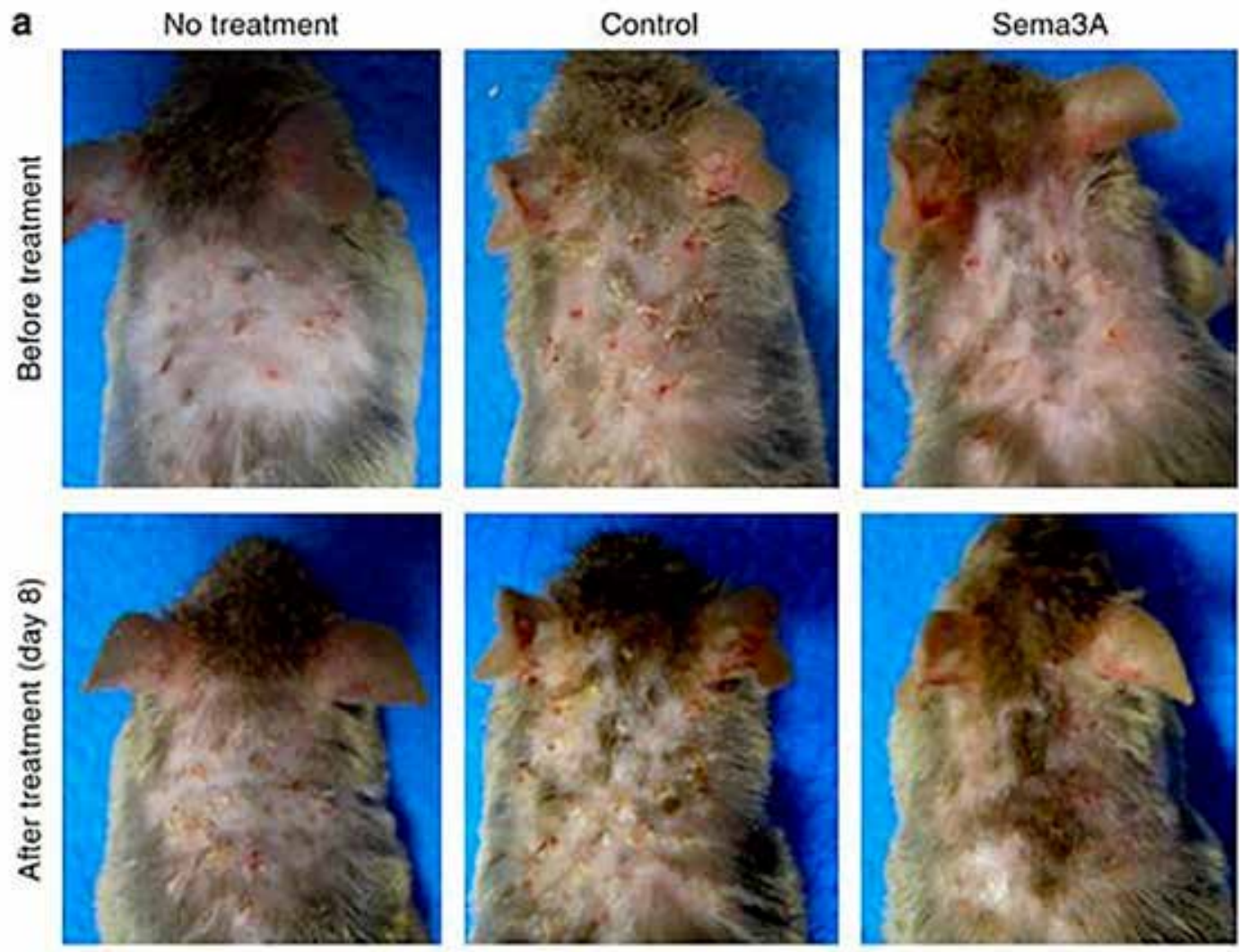

Figure 4:

Atopic lesions. Evaluation of animals before and after semaphorin topical application

Source: Yamaguchi et al, $2008 .{ }^{15}$

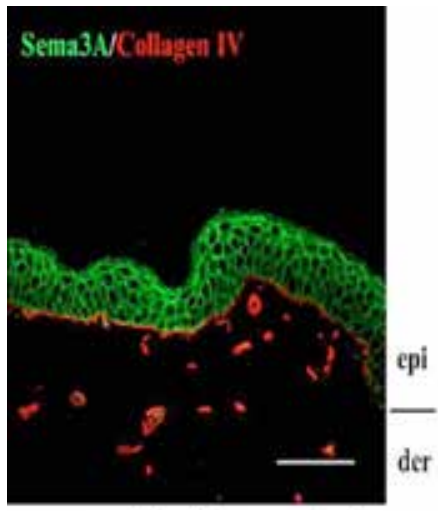

A Healthy control

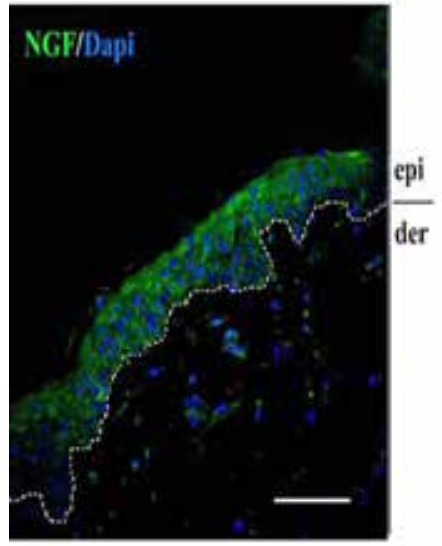

B Healthy control

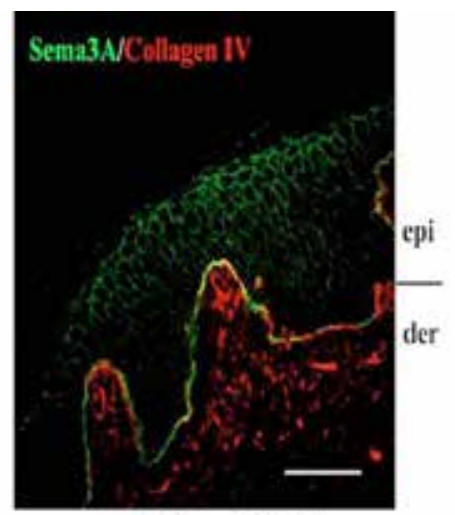

Before PUVA

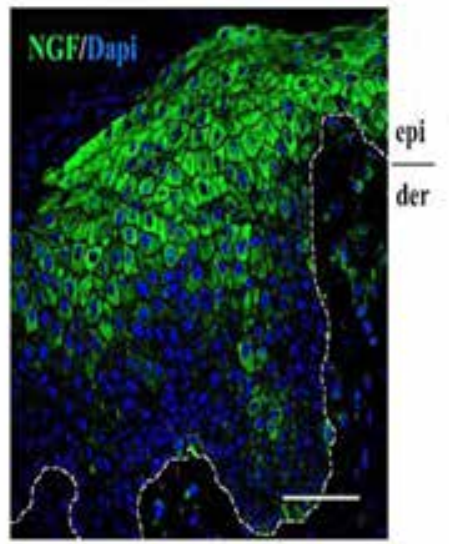

Before PUVA

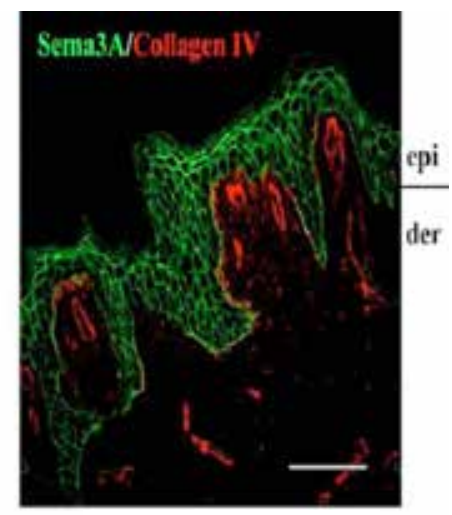

After PUVA

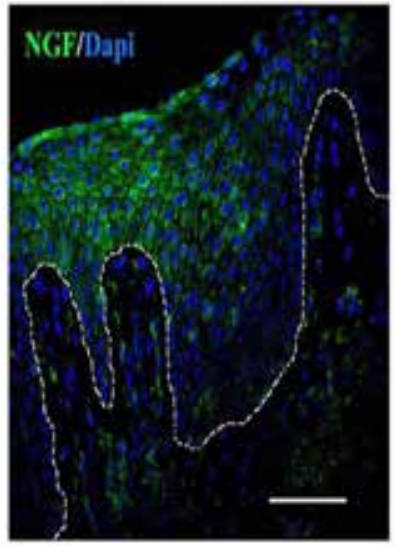

After PUVA
Figure 5:

A: Presence of semaphorin 3A (marked in green) in the normal skin (1) and in atopic lesions before (2) and after (3) PUVA.

B: Presence of NGF (marked in green) in non-atopic skin (1) and atopic lesions before (2) and after (3) PUVA

Source: Tominaga $\mathrm{M}$ et $\mathrm{al}$ 2009. ${ }^{11}$ 
Cocultures of nerves and keratinocytes of atopic individuals revealed that these epidermal cells produce high levels of NGF, which increases the growth of nerve fibers, emphasizing their importance for the neural stimulation. It was also demonstrated that the calcitonin gene-related peptide (CGRP) participates in the stimulatory process. ${ }^{19-22}$

\section{Neuropeptides}

Neuropeptides comprise a group of more than 50 substances that act as neuromodulators, neurotransmitters and hormones, performing numerous local and systemic functions. In the skin, the neuropeptides substance $\mathrm{P}(\mathrm{SP})$, vasoactive intestinal peptide (VIP), somatostatin-related peptide, calcitonin gene-related peptide (CGRP), gastrin-releasing peptide (GRP), neuropeptide Y (NPY), and neurotensin respond to different stimuli. Other peptides - isoleucine (PHI), neurokinins A and $\mathrm{B}$, acetylcholine and catecholamines, endorphins and enkephalins - also respond to different stimuli. ${ }^{23,24}$

Mechanical, thermal, electrical, biological, chemical, or stimulation resulting from inflammatory mediators in the skin, may induce the release of these neuropeptides stored in skin blisters, determining arteriolar dilation, with an increase of local blood flow and extravasation of plasma and platelets, as well as mast cell attraction and degranulation, histamine release and even popular rash formation (Figure 6). This reaction, called "neurogenic inflammation", is specifically mediated by substance P (SP), by CGRP and by GRP, locally stored in vesicles at the ends of unmyelinated afferent nerve fibers and, to a lesser extent, in myelinated fibers C. ${ }^{23}$

The "neurogenic inflammation", as noted above, is a bidirectional phenomenon, since the released SP stimulates keratinocytes to multiply and to produce NGF, which, by retrograde neuronal tracing, reaches the neuronal cell bodies, stimulating its tropism. It results in a greater production of neuropeptides by the nerve (Figure 2). ${ }^{25}$ In addition, NGF acts autocrinally in the keratinocyte, increasing its multiplication and providing an expansive character to the process. Substance $\mathrm{P}(\mathrm{SP})$, a neuropeptide much more potent than histamine, is secreted not only by the nerves, but also by eosinophils, lymphocytes and dendritic cells, acting through binding to neurokinin-1 receptor (NK-1R) in the development of intestinal, musculoskeletal and respiratory inflammatory diseases. ${ }^{24,26}$

Different substances can induce the release of SP by the nerves and these include allergens, histamine, prostaglandins and leukotrienes, with an increase of monocytes chemotaxis and of IL1, IL-8, IL-10 and TNF-alpha production, as well as of mast cells degranulation and polymorphonuclear adhesion to endothelium, capable of worsening the AD. ${ }^{26-28}$

The vascular endothelial growth factor (VEGF), considered the most potent stimulator of angiogenesis, is strongly induced in mast cells by SP, acting in synergy with this neuropeptide. ${ }^{29}$ Sensory nerve fibers touching mast cells can be demonstrated in AD (Figure 7). ${ }^{3}$

Another powerful vasodilator, CGRP, expressed peripherally and in the central nervous system via specific receptors, have different responses mediated by Th1 and Th2 lymphocytes, being able to inhibit Th1 responses and the migration of dendritic dermal cells to lymph nodes, as well as stimulating the production of IL4. ${ }^{29-31}$ Nerve fibers containing CGRP neuropeptide are specifically involved and increased both in atopic animals and in patients with AD. Its serum levels are related to pruritus, and its production is stimulated by the addition of inflammatory mediators. ${ }^{31,32}$

Recent studies have demonstrated the involvement of gastrin-releasing peptide (GRP) in AD, mediating the itching sensation in the spinal cord and the increase of cutaneous fibers containing this neuropeptide in atopic NC/Nga animals. ${ }^{7,32,33}$ From hematopoiesis to antigen-specific response of T-lymphocyte, the SP, CGRP and other tachykinins modulate the maturation and cellular responses. ${ }^{34,35}$

Stability and control of neuropeptides actions depend on the local activity of neuropeptidases able to limit their actions. Inactivation of neutral endopeptidase (NEP) and angiotensin-converting enzyme (ACE) results in relative abundance of SP and bradykinin, which amplifies awareness and response to allergens. ${ }^{36,37}$

The importance of these neuropeptidases in the development of atopy is yet to be established. Both ACE and NEP are detectable in endothelial cells, fibroblasts and keratinocytes. The benefits of glucocorticoids administration in $\mathrm{AD}$ are also due to the reduction of neuropeptide production and its receptors.
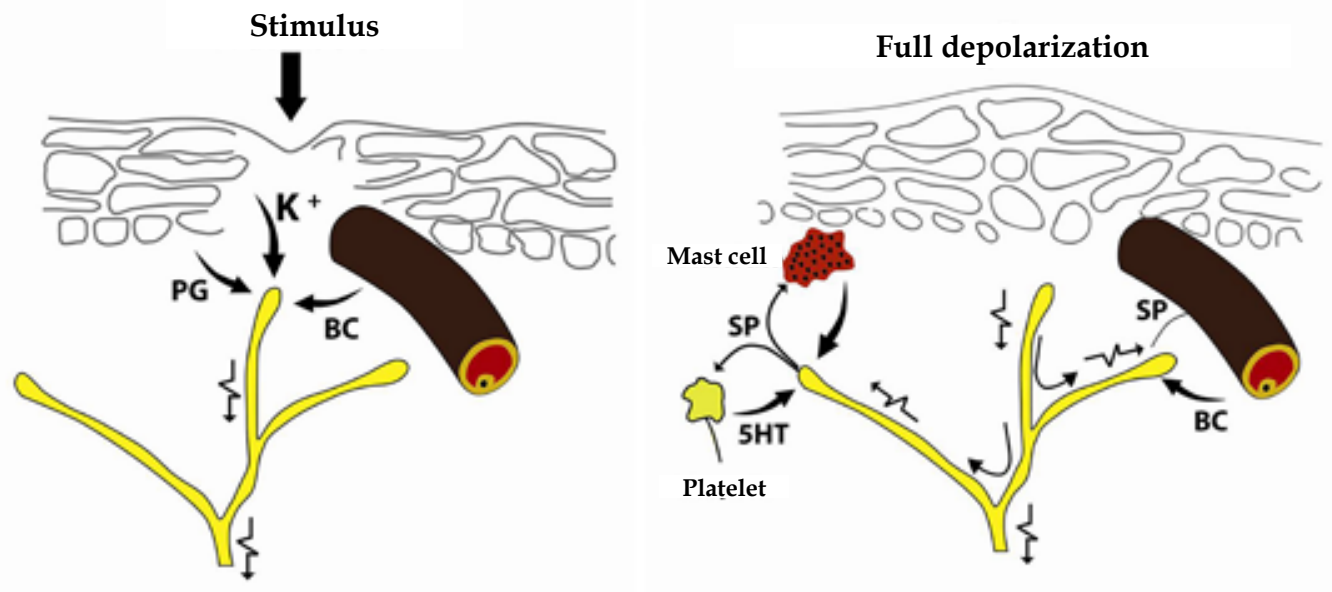

Figure 6:

Mechanism of neurogenic inflammation formation. Stimuli (physical, chemical or biological) that promote the neuropeptides release, including substance $\mathrm{P}(\mathrm{SP})$, attract and degranulate mast cells, stimulate adhesion of platelets, release of histamine and 5HT, vasodilation and plasma outlet with formation of an urticarial papule

Adapted from: Rathwell JP et $a l, 2015 .{ }^{25}$ 


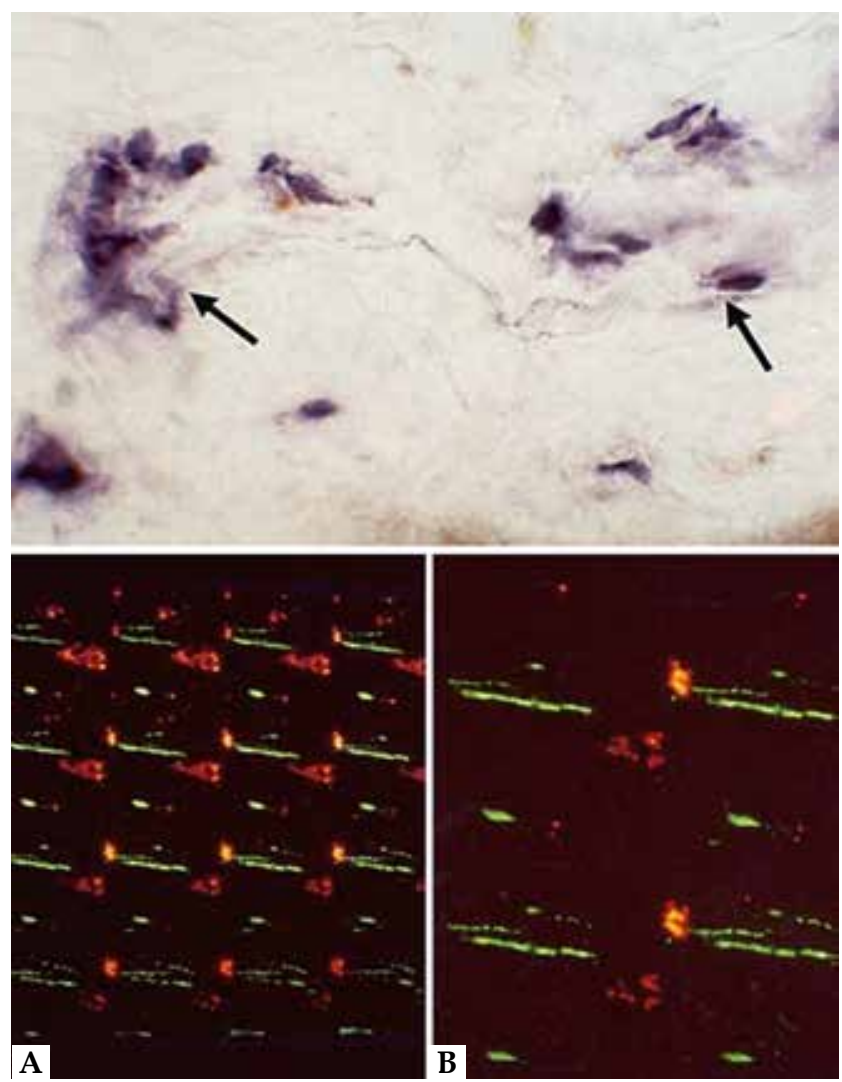

Figure 7: A: Nerve touching mast cells in AD. B: Sensory nerves in $\mathrm{AD}$ (marked in green)

Source: Järvikallio et al, 2003. ${ }^{3}$

\section{Neurotrophins and AD}

Neurotrophins belong to a large family of growth factors that control development, maintenance and apoptosis of neurons, in addition to playing multiple and pivotal regulatory and physiological functions, particularly in the immune system and in the skin. Its biological effects depend on the context of receptors expression on target cells and a group of intracellular signaling molecules that connect with their biochemical pathways and cellular different destinations.

NGF, BDNF, NT-3 and NT-4/5 are also defined as members of the neurotrophins family. ${ }^{21,22}$ Despite the search for changes in gene regions related to controlling the production of these neurotrophins that may contribute to the onset of $\mathrm{AD}$, polymorphisms of NGF or BDNF genes were not found. ${ }^{38}$

\section{NGF}

NGF is considered the major mitogen for keratinocytes, being more potent than epidermal growth factor (EGF). Produced by basal and suprabasal keratinocytes, lymphocytes, mast cells and other cell components, it is essential to the growth and maintenance of central and peripheral neurons. ${ }^{39}$ It is considered an AD activity index, and has, in the stratum corneum, levels that reflect the severity of the disease. ${ }^{6,40,41}$
This neurotrophin mediates its effects by binding to two classes of transmembrane receptors: one with high affinity (tropomyosin-related kinase A - TrkA) and other with low affinity (p75). ${ }^{42}$ The expression of these receptors is elevated in $\mathrm{AD}$ and is present in mast cells and keratinocytes cultures. ${ }^{6,43,44}$

In patients with $\mathrm{AD}$ and in strains of atopic mice, mast cells show strong expression of the receptor $\mathrm{p} 75 .{ }^{3,45,46} \mathrm{DS}-\mathrm{Nh}$ mice, which develop dermatitis similar to $\mathrm{AD}$, have elevated serum histamine levels and nerve fibers extending around mast cells and invading the lesional epidermis. ${ }^{47}$ Human eosinophils produce neurotrophins and secrete NGF under neurological stimuli, which may contribute to the intensification of the neural response in patients. ${ }^{48}$ Presence of nerves touching mast cells is observed in lesions of patients with AD. ${ }^{3}$

In other pole of atopy, the atopic rhinitis, NGF is demonstrable through the entire thickness of the affected epithelium, but only in the basal area of the non-affected epithelium. In this condition, there is an increase in the mucosa of the number and extent of nerve fibers and NGF (Figure 8) in relation to non-atopic mucosa, which is a relevant aspect to its conceptualization as "vasomotor rhinitis". ${ }^{49}$ Elevated serum levels of NGF have also been documented in patients with asthma. In this condition, there is neurotrophins mediation in the inflammatory process. ${ }^{50}$

The evaluation of atopic animals of the NC/Nga strain showed increase of intraepidermal nerve fibers, of NGF, and of the amphiregulin protein, from the family of epidermal growth factor, in addition to the reduction of cell adhesion molecules in the skin, indicative of enzyme participation in the aggravation of the process. ${ }^{51,52}$ The evaluation of nerve fibers development in culture in collagen, stimulated by the addition of NGF, proved that the fibers growth is enabled by the increase of metalloproteinase-2. This peptidase is produced by cutaneous nerves under NGF stimulus. By inactivation of metalloproteinase, neural growth is inhibitable, as well as with the addition of semaphorin 3A. ${ }^{8,53}$ Therapy with psoralen and ultraviolet A improves semaphorin and NGF levels, and modulates epidermal innervation. ${ }^{14}$

In a prospective study with 40 atopic and 80 nonatopic pregnant women, the analysis of umbilical cord blood showed that increased NGF levels may be considered a biomarker predictive of atopy rather than IgE levels. ${ }^{54}$ Severity of AD lesions is related to the levels of receptors for NGF and SP in isolated eosinophils of patients and to the severity of atopy. ${ }^{55}$ These levels decrease with the use of calcineurin inhibitors and show large circadian fluctuations, possibly linked to stress or neurophysiological mechanisms. ${ }^{13,56}$

\section{BDNF}

BDNF, a neurotrophin engaged in the development and neural regeneration, has high levels in serum, plasma and eosinophils of patients with $\mathrm{AD}$ in activity, regressing with its remission. ${ }^{57}$ Eosinophils of these patients stimulated in vitro elaborate large amounts of BDNF. ${ }^{58}$ Eosinophils, in addition to producing and storing BDNF, have high expression of p75 and TrkB receptors, whose activation protects them from apoptosis. ${ }^{59,60}$ 

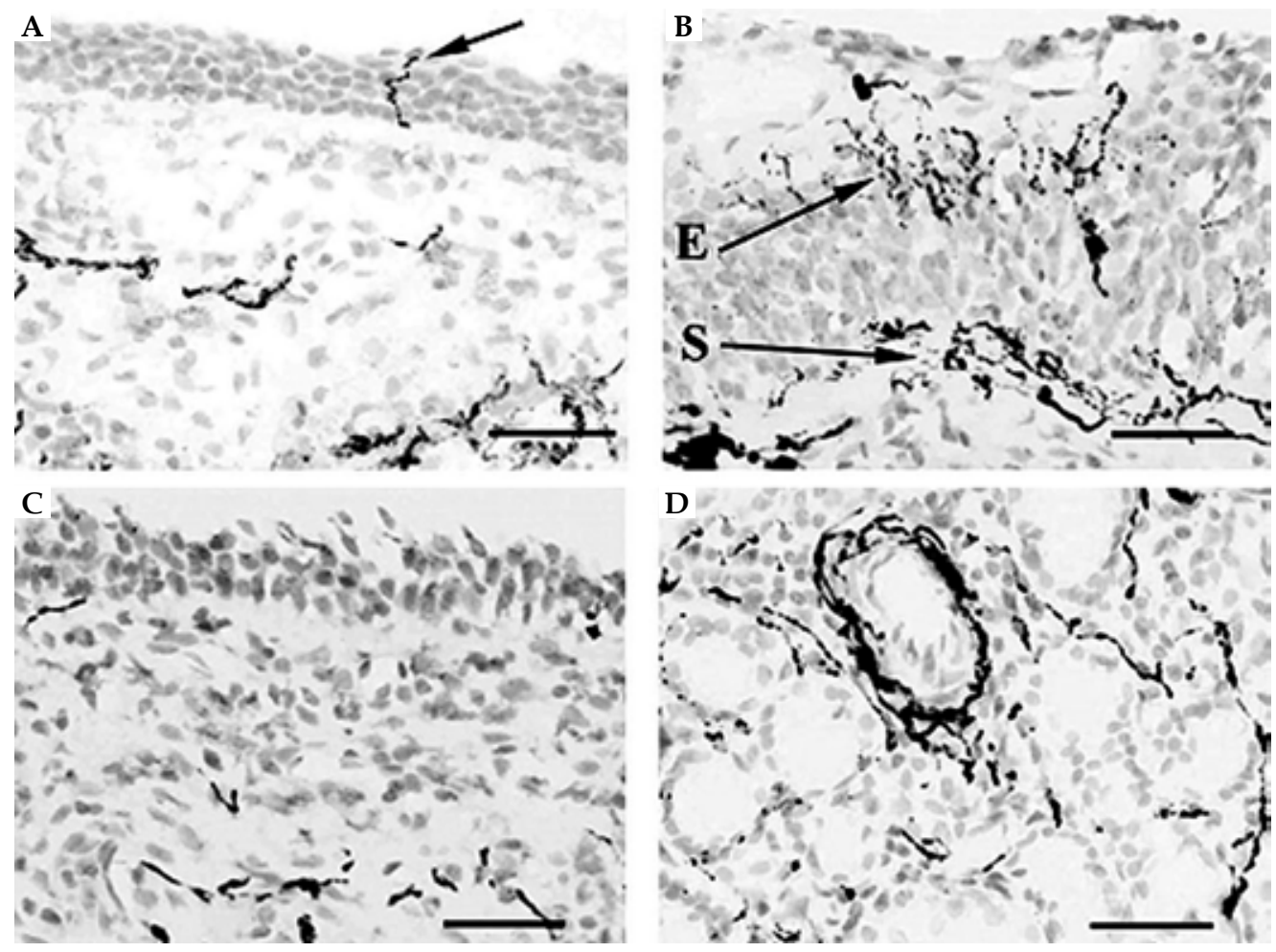

Figure 8:

Nasal mucosa (atopic rhinitis). Neural response in normal mucosa (A) and in allergic rhinitis (B) after physical stimulation (touch with monofilament). Immunoreactive nerve fibers (PGP 9.5) viewed individually in the control group (arrow) or in groups (arrow). Few fibers in the control group (C). Fibers present in glands and mucosal vasculature with rhinitis (D)

Source: O'Hanlon S et al, 2007.
Stress, neuropeptides, neurotrophins and AD

In $\mathrm{AD}$, there are specific neurobiological skin changes. ${ }^{61} \mathrm{In}$ animals, during periods of stress, increased release of neurotransmitters and neural factors involved in neurogenic inflammation is observable, greatly amplifying immune responses with hyperinnervation of epidermis with local mediation by NGF, contributing to mast cells degranulation, inflammation worsening, skin hyperplasia, pro-allergenic cytokines induction, and cellular infiltration. ${ }^{62,63}$

The increase of NGF and its receptor TrkA has been demonstrated in atopic animals subjected to stress. ${ }^{63}$ Tests on atopic animals of NC/Nga strain exposed to chronic stress showed increased SP not only in the skin, but also in the hypothalamus, aspects that were reverted by the administration of NGF inactivating antibodies. ${ }^{64}$

Psychological stress has adjuvant effect in skin dendritic cells, and SP is considered a key mediator of this response, capable of increasing by about $30 \%$ the vascular eosinophilic infiltration parameters, of vascular cell adhesion, and of skin thickness. ${ }^{65}$ Such exacerbation is associated with increased neurogenic inflammation and involves more contact of Langerhans cells with epidermal nerve fibers containing SP. Serum NGF levels present not only circadian fluctuations, but also fluctuations possibly related to stress. ${ }^{57}$

\section{$A D$, genetic aspects of filaggrin and neural relation}

Filaggrin is the main source of natural moisturizers in stratum corneum: the pyrrolidone carboxylic acid (PCA) and urocanic acid. These natural moisturizers are dependent on the filaggrin genotype, and their level of genetic alteration is related to the severity of atopy. There is at least one mutation in the filaggrin gene in $50 \%$ of patients with $\mathrm{AD}^{66,67}$ that is associated with increased IL- 1 in the stratum corneum both in $\mathrm{AD}$ patients and in murine models with deficiency of filaggrin. ${ }^{68}$

$\mathrm{AD}$ is also associated with increased serine proteases and with large increase of kallikrein and plasmin, which contributes to skin permeability. ${ }^{69}$ The xerotic aspects, genetically determining of $\mathrm{AD}$, relate not only to penetration and exposure to allergens, but also to a greater exposure of cutaneous nerves and ion channels that act as environmental sensors.

Cutaneous stimulation of these sensors determines the release of neuropeptides and the intensification of responses considered neuroimmunes. The level of perception of itching by applying electric current varies according to the xerosis determined by filagrin changing. ${ }^{70}$ The importance of the lipid mantle in the development of sensory structures and in the perception of itching is demonstrable in atopic mice through skin degreasing with acetone. After 16-48 hours, the penetration of nerves in the skin is observed, reaching its maximum in 24 hours. ${ }^{71}$ This process induces xerosis and nerves penetration, producing itching, semaphorin molecule reduction, and NGF increase, thus developing typical atopic lesions. ${ }^{12}$ In these animals, contact with antigens and their presentation to the immune system are facilitated by the reduced epidermal barrier. ${ }^{72}$

The importance of filaggrin was corroborated by a study conducted in Denmark evaluating a large number of individuals with genetic alteration of filaggrin, which showed in this population the increased risk of AD as well as of hand eczema. ${ }^{73,74}$ 
Once the skin barrier is disrupted by filaggrin mutation or by external factors, antigens penetration may occur. Haptens penetration initially produces Th1 response, but the repeated penetration of these antigens can elicit Th2 responses. Th2 cells produce IL-31, which inhibits filaggrin differentiation.

In experimental models, IL-31 inhibits the epidermis differentiation, causing reduction of its thickness by changing the alignment of basal cell and reducing the development of the granulosa layer with deep repression of terminal differentiation markers, including filaggrin Nobbe. ${ }^{75}$

\section{IL-31}

IL-31 is a cytokine produced by Th2 cells, mainly by CD4(+), and induced by IL- 4 , acting on a wide spectrum of cells with immune and nonimmune activity, regulating from hematopoiesis to immune response and causing intestinal inflammation, airway hypersensitivity, itching and eosinophils and fibroblasts stimuli. ${ }^{76-88}$

This cytokine intensifies itching and show levels related with the severity of AD in humans and in atopic animals. ${ }^{75,81,83,86,87}$ In these animals (CN/Ngs), anti-IL-31 antibodies improve itching and scratching. ${ }^{88}$

The activation of IL-31 receptor in keratinocytes induces calcium influx, contributing to the intensification of AD. ${ }^{84}$ Recently, it was demonstrated that sensory neurons express receptors for IL31, which can be critical to the perception of pruritus. ${ }^{89}$

\section{Staphylococci in AD and development of neural fibers}

Staphylococcus aureus are usually present not only in AD lesions but also in non-lesional areas of patients. ${ }^{90,91}$ Its colony number is parallel to the severity of lesions, production of cytokines, number of mast cells in tissue, level of $\operatorname{IgE}$ and eosinophils in the peripheral blood. Exotoxin secreted by S. aureus act as superantigens that induce T-cell proliferation and IL-31 production much more extensively in these patients than in normal subjects. ${ }^{92,93}$

In $64.1 \%$ of 39 patients, the severity of $\mathrm{AD}$, correlated with the level of the skin barrier function (transepidermal water loss rate) is parallel to the level of colonization by S. aureus. ${ }^{90}$ Macrophages and monocytes of patients with $\mathrm{AD}$ show reduced expression of cytokine CXCL10 induced by interferon gamma in response to the staphylococcal toxin, impairing the recruitment of defensive cells. ${ }^{94}$

In one experiment using the enterotoxin B of staphylococci in animal skin, it was demonstrated the proliferative presence of sensory C-fibers, increase of NG, expression and release of SP, as well as increased presence of NK-1 receptors for tachykinin and NGF. The importance of staphylococcus presence was also observed in atopic dogs. ${ }^{95,96}$ Although both the staphylococcal protein A (SPA) and SEA are responsible for exacerbation of AD, only SEA was able to induce adhesion and increase of inflammatory molecules in human keratinocytes $\mathrm{HaCaT}$ and human umbilical venous endothelial cells. ${ }^{91}$

Cutaneous receptors for environmental stimuli, calcium, skin barrier and AD

Skin elements responsible for perceiving and communicating to the nerves information generated by environmental stimuli for neuropeptides release begin to be understood through demonstration of a family of skin receptors/sensors called transient receptor potential (TRP). ${ }^{97,98}$ These are families of canalicular membrane proteins resulting from specific genes activity expressed in nerves, keratinocytes, white blood cells and other cell types, classified according to their sensitivity to pharmacological groups.

The activation of voltage-dependent channels allows calcium to enter the cell, ${ }^{99}$ determining, depending on its cell condition, a specific activity. We depend on these channels for pain perception, sensory functions and immune response. ${ }^{100}$ TRPV1 (transient receptor potential vanilloid type 1 ) is a nonselective cation channel expressed in keratinocytes, other epithelial tissues and in C and A-delta fiber that are upregulated in AD. If activated by heat or other stimuli, they provide SP release, extending neurogenic inflammation and altering the skin barrier. ${ }^{101-105}$

The increase in cytosolic Ca2+ is sufficient to initiate endothelial cell retraction and increase vascular permeability, neurogenic inflammation and pruritus. ${ }^{106-109}$ The prolonged increase in Ca2+ concentration, by TRPC6 subtype, determines the proliferation and differentiation of keratinocytes, and production of inflammatory cytokines. ${ }^{109-113}$ Spontaneous atopic animals (NC/TnD mice) show abnormal responses of itching to external stimuli via TRPV1, compared with non-atopic (BALB/c and B6), suggesting that these channels are modulators of pruritus. ${ }^{107,114}$ PAC-14028 antagonist of TRPV1, tested in atopic animals, was able to suppress the symptoms of AD resulting from stimulation of these receptors. ${ }^{115-117}$ Antagonists of these channels can also suppress the symptoms of AD by accelerating the recovery of the skin barrier. ${ }^{115}$

L-type ion channels, also present in keratinocytes and mast cells, have involvement participation in controlling the differentiation of these cells. ${ }^{118,119}$ These channels (L-Type) also participate in the regulation of calcium ions entry for the release of CGRP and gastrin-releasing peptide. ${ }^{113,119,120}$

The regulation of these channels is the subject of trials with different substances, aiming potential therapeutic agents for AD.

\section{The complex network of AD}

Atopic dermatitis is characterized by a complex network comprising skin barrier dysfunctions, and neural/immune/allergic and pruritus disorders. When the barrier is disrupted by genetic alterations or by aggression of wide-ranging kinds, the skin is exposed to penetration of external stimuli and to responses of its neural components. This reduction provides greater exposure and hapten penetration. The intensification of responses to hapten by neuro-encephalo-cutaneous network characterizes the aspects achieved in atopic individuals.

Knowledge on the neuro-cutaneous dynamic involved in this condition is essential for understanding the therapeutic targets and the numerous drugs that are currently being studied in laboratory trials.

\section{ACKNOWLEDGMENTS}

The authors would like to thank librarians Verônica Novaes Esteves (UFF) and Rosalyn Leite (SBD) for the excellent work they have performed. 


\section{REFERENCES}

1. Tobin D, Nabarro G, Baart de la Faille H, van Vloten WA, van der Putte SC, Schuurman HJ. Increased mumber of immunoreative nerve fibers in atopic dermatitis. J Allergy Clin Immunol. 1992;90:613-22.

2. Ostlere LS, Cowen T, Rustin MH. Neuropeptides in the skin of patients with atopic dermatitis. Clin Exp Dermatol. 1995;20:462-7.

3. Järvikallio A, Harvima IT, Naukkarinen A. Mast cells, nerves and neuropeptides in atopic dermatitis and nummular eczema. Arch Dermatol Res. 2003;295:2-7.

4. Scuri M, Samsell L, Piedimonte $G$. The role of neurotrophins in inflammation and allergy.Inflamm Allergy Drug Targets. 2010;9:173-80

5. Tominaga M, Takamori K. An update on peripheral mechanisms and treatments of itch. Biol Pharm Bull. 2013;36:1241-7

6. Takano N, Sakurai T, Kurachi M. Effects of anti-nerve growth factor antibody on symptoms in the NC/Nga mouse, an atopic dermatitis model. Pharmacol Sci. 2005;99:277-86

7. Kalil-Gaspar P. Neuropeptideos na pele. An Bras Dermatol. 2003;78:483-498.

8. Pincelli C, Steinhoff M. Recapitulating atopic dermatitis in three dimensions: cross talk between keratinocytes and nerve fibers. J Invest Dermatol. 2013;133:1465-7.

9. Takano N, Sakurai T, Ohashi Y, Kurashi M. Effects of high-affinilty nerve growth factor receptor inhibitors on symtoms in the NCNga mouse atopic dermatitis model. Br J Dermatol 2007;156:241-6.

10. Wallegren J, Sundler F. Phototherapy reduces the number of epidermal and CGRPpositive dermal nerves fibers. Acta Derm Venereol. 2004;84:111-5.

11. Tominaga $\mathrm{M}, \mathrm{Ogawa} \mathrm{H}$, Takamori K. Psoralen-ultraviolet $\mathrm{A}$ therapy alters epiderma Sema3A and NGF levels and modulates epidermal innervation in atopic dermatitis. J Dermatol Sci. 2009;55:40-6.

12. Kamo A, Tominaga M, Tengara S, Ogawa H, Taakamori K. Inhibitory effects of UVB-based therapy on dry skin-inducible nerve growth in acetone-treated mice. $J$ Dermatol Sci. 2011;62:91-7.

13. Kim HO, Lee $\mathrm{CH}$, Ahn HK, Park CW. Effects of tacrolimus ointment on the expression of substance $P$, nerve growth factor, and neurotrophin-3 in atopic dermatitis. Int J Dermatol. 2009;48:431-8.

14. Tominaga M, Ogawa $\mathrm{H}$, Takamori K. Decreased production of semaphorin $3 \mathrm{~A}$ in the lesional skin of atopic dermatitis. Br J Dermatol. 2008;158:842-4.

15. Yamaguchi J, Nakamura F, Aihara M, Yamashita N, Usui H, Takei K, et al. Semaphorin3A alleviates skin lesions and scratching behavior in NC/Nga mice, an atopic dermatitis model. J Invest Dermatol. 2008;128:2842-9.

16. Negi 0, Tominaga M, Tengara S, Kamo A, Taneda K, Suga $Y$ et al. Topically appliedsemaphorin $3 \mathrm{~A}$ ointment inhibits scratching behavior and improves skin inflammation in NC/Nga mice with atopic dermatitis. J Dermatol Sci. 2012;66:3743.

17. Tominaga M1, Takamori K. J Dermatol. Itch and nerve fibers with special reference to atopic dermatitis: therapeutic implications. 2014;41:205-12.

18. Yamaguchi J, Aihara M, Kobayashi Y, Kambara T, Ikezawa Z. Quantitative analysis of nerve growth factor (NGF) in the atopic dermatitis and psoriasis horny layer and effect of treatment on NGF in atopic dermatitis. J Dermatol Sci. 2009;53:48-54.

19. Ulmann L, Rodeau JL, Danoux L, Contet-Audonneau JL, Pauly G. Trophic effects of keratinocytes on the axonal development of sensory neurons in a coculture model. Eur J Neurosci. 2007:26:113-25

20. Pereira U, Boulais N, Lebonvallet N, Lefeuvre L, Gougerot A, Mizery L. 2010 Development of an in vitro coculture of primary sensitive pig neurons and keratinocytes for the study of cutaneous neurogenic inflammation. Exp Dermatol. 2010 0ct:19(10):931-5.

21. Roggenkamp D1, Köpnick S, Stäb F, Wenck H, Schmelz M, Neufang G. . Epidermal nerve fibers modulate keratinocyte growth via neuropeptide signaling in an innervated skin model. J Invest Dermatol. 2013 Jun;133:1620-8.

22. Roggenkamp D, Falkner S, Stäb F, Petersen M, Schmelz M et al. Atopic keratinocytes induce increased neurite outgrowth in a coculture model of porcine dorsal root ganglia neurons and human skin cells. J Invest Dermatol. 2012;132:1892-900.

23. Misery L. [Neuro-immuno-cutaneous system (NICS)]. Pathol Biol (Paris). 1996;44:867-74

24. Akiyama T, Tominaga M, Takamori K, Carstens Ml, Carstens E. Roles of glutamate, substance $P$, and gastrin-releasing peptide as spinal neurotransmitters of histaminergic and nonhistaminergic itch. Pain. 2014;155:80-92.

25. Rathwell JP, Fields H. Pain: Pathophysiology and management. In: Kasper DL. Harrison's Principles of Internal Medicine. 19th ed. New York: Ed McGrow Hill; 2015.

26. Foreman JC. . Neuropeptides and the pathogenesis of allergy. Allergy. 1987;42:111.

27. O'Connor TM, O'Connell J, O'Brien DI,, Bredin CP, Shanahan F. Physiol.The role of substance $P$ in inflammatory disease. J Cell 2004;201:167-80.

28. Kim KH, Park KC, Chung JH, Choi HR. The effect of substance P on periphera blood mononuclear cells in patients with atopic dermatitis. J Dermatol Sci. 2003;32:115-24.
29. Brain SD, Williams TJ. Inflammatory oedema induced by synergism between calcitonin gene-related peptide (CGRP) and mediators of increased vascular permeability. Br J Pharmacol. 1985 ;86:855-60.

30. Shaik-Dasthagirisaheb YB, Varvara G, Murmura G, Saggini A, Potalivo G, Caraffa A et al. Vascular endothelial growth factor (VEGF), mast cells and inflammation. Int J Immunopathol Pharmacol. 2013;26:327-35.

31. Averbeck B, Reeh PW. Interactions into inflammatory mediators stimulating release of calcitonin gene-related peptide, substance $P$ and prostaglandin $E$ (2) from isolated rat skin. Neurofarmacology. 2001;40:416.

32. Kigami S, Sugaya M, Suga H, Morimura S, Morimura S, Kai H. Serum gastrinreleasing peptide levels corrlatee with pruritus in patients with atopic dermatitis. $J$ Invest Dermatol. 2013:133:1673-5.

33. Sun YG, Chen ZF. A gastrin-releasing peptide receptor mediates the itch sensation in the spinal cord. Nature. 2007;448:700-3.

34. Bost KL. Tachycinin-mediated modulation of immune response. Front Biosci. 2004:1:3331-2

35. Patel N, Castillo M, Rameshwar P. An in vitro method to study the effects of hematopoietic regulators during immune and blood cell development. Biol Proced Online. 2007:9:56-64.

36. Bak H, Lee WJ, Lee YW, Chang SE, Choi JH, Kim MN et al. Expression of neuropeptides and their degrading enzymes in ACD. Clin Exp Dermatol. 2010 Apr;35(3):318-23

37. Lim YY1, Kim HM, Lee HI, Mun SK, Kim CW, Kim MN, Kim BJ. A comparison of neuropeptide expression in skin with allergic contact dermatitis in human and mouse. Int J Dermatol. 2012:51:939-46.

38. Hoffjan S, Parwez Q, Petrasch-Parwez E, Stemmler S. Variation in the BDNF and NGFB genes in German atopic dermatitis patients. Mol Cell Probes. 2009;23:35-8.

39. Wilkinson DI, Theeuwes MJ, Farber EM. Nerve growth factor increases the mitogenicity of certain growth factors for cultured human keratinocytes: a comparison with epidermal growth factor. Exp Dermatol. 1994;3:239-45.

40. Yamaguchi J, Aihara M, Kobayashi Y, Kambara T, Ikezawa Z. Quantitative analysis of nerve growth factor (NGF) in the atopic dermatitis and psoriasis horny layer and effect of treatment on NGF in atopic dermatitis. J Dermatol Sci. 2009;53:48-54.

41. Takano N, Sakurai T, Ohashi Y, Kurachi M. Effects of high-affinity nerve growth factor receptor inhibitors on symptoms in the NC/Nga mouse atopic dermatitis model. Br J Dermatol. 2007;156:241-6.

42. Toyoda M, Nakamura M, Makino T, Hino T, Kagoura M, Morohashi M. Nerve growth factor and substance $P$ are useful plasma markers of disease activity in atopic dermatitis. Br J Dermatol. 2002;147:71-9.

43. Raap U, Deneka N, Bruder M, Kapp A, Wedi B. Differential up-regulation of neurotrophin receptors and functional activity of neurotrophins on periphera blood eosinophils of patients with allergic rhinitis, atopic dermatitis and nonatopic subjects. Clin Exp Allergy. 2008;38:1493-8.

44. Dou YC, Hagströmer L, Emtestam L, Johansson 0. increased nerve growth factor and its receptors in atopic dermatitis: an immunohistochemical study. Clin Exp Allergy. $2008 ; 38: 1168-73$.

45. Ficher TC, Laurenstein HD, Serowka F, Pilzner C, Groneberg DA, Welker P. Panneurotrophin receptor p75NTR expression is strongly induced in lesional atopic mast cells. Clin Exp Allergy. 2008;38:1118-73.

46. Horigome K, Pryor JC, Bulock ED, Jonhson EM Jr. Mediator release from mast cells by nerve growth factor. Neuritrophin specivity and receptor mediation. J Bio Chem. 1993:268:14881-7.

47. Yoshioka T, Hikita I, Asakawa M, Hirasawa T. Spontaneous scratching behaviour in DS-Nh mice as a possible model for pruritus in atopic dermatitis.Immunology. 2006 Jul;118(3):293-301.

48. Kobayashi H, Gleich GJ, Butterfield JH, Kita H. Human eosinophils produce neurotrophins and secrete nerve growth factor on immunologic stimuli. Blood. 2002:99:2214-20.

49. O'Hanlon S, Facer P, Simpson KD, Sandhu G, Saleh HA, Anand P. Neuronal markers in allergic rhinitis: expression and correlation with sensory testing. Laryngoscope. 2007:117:1519-27.

50. Bonini S, Lambiase A, Bonini S, Angelucci F, Magrini L, Manni L et al. Circulating nerve growth factor levels are increased in humans with allergic diseases and asthma. Proc Natl Acad Sci U S A. 1996;93:10955-60.

51. Tominaga M, Ozawa S, Ogawa H, Takamori K. A hypothetical mechanism of intraepidermal neurite formation in NC/Nga mice with atopic dermatitis. J Dermato Sci. 2007;46:199-210.

52. Tominaga M, Tengara S, Kamo A, Ogawa H, Takamori K. Matrix metalloproteinase-8 is involved in dermal nerve growth: implications for possible application to pruritus from in vitro models. J Invest Dermatol. 2011:131:2105-12.

53. Kumamoto J, Nakatani M, Tsutsumi M, Goto M, Denda S, Takei K, et al. Coculture system of keratinocytes and dorsal-root-ganglion-derived cells for screening neurotrophic factors involved in guidance of neuronal axon growth in the skin. Exp 
Dermatol. 2014:23:58-60.

54. Wang IJ, Hsieh WS, Guo YL, Jee SH, Hsieh CJ, Hwang YH et al. Neuro-mediators as predictors of paediatric atopic dermatitis. Clin Exp Allergy. 2008;38:1302.

55. Toyoda M, Nakamura M, Makino T, Morohashi M. Localization and content of nerve growth factor in peripheral blood eosinophils of atopic dermatitis patients. Clin Exp Neurogenic markers of the inflammatory process in atopic dermatitis: relation to the severity and pruritus. Allergy. 2002;33:950-5.

56. Papoiu AD, Wang H, Nattkemper L, Tey HL, Ishiuji Y, Chan YH et al. A study of serum concentrations and dermal levels of NGF in atopic dermatitis and healthy subjects. Neuropeptides. 2011;45:417-22.

57. Teresiak-Mikołajczak E, Czarnecka-Operacz M, Jenerowicz D, Silny W. Neurogenic markers of the inflammatory process in atopic dermatitis: relation to the severity and pruritus. Postepy Dermatol Alergol. 2013;30:286-92.

58. Raap U, Goltz C, Deneka N, Bruder M, Renz H, Kapp A, Wedi B. Brain-derived neurotrophic factor is increased in atopic dermatitis and modulates eosinophil functions compared with that seen in nonaptic subjects. J Allergy Clin Immunol. 2005;115:1268-75

59. Raap U, Braunstahl GJ, The role of neurotrophins in The pathophysiology of allergic rhinitis. Curr Opin Allergy Clin Ummunol. 2010;18-13.

60. Nassenstein C, Braun A, Erpenbeck VJ Lommatzsch M, Schmidt S, Krug N et al. The neurotrophins nerve growth factor, brain-derived neurotrophic factor, neurotrophin-3, and neurotrophin-4 are survival and activation factors for eosinophils in patients with allergic bronchial asthma. J Exp Med. 2003;198:45567

61. Misery L. Atopic dermatitis and the nervous system. Clin Rev Allergy Immunol. 2011;41:259-66

62. Peters EM, Kuhlmei A, Tobin DJ, Müller-Röver S, Klapp BF, Arck PC. Stress exposure modulates peptidergic innervation and degranulates mast cells in murine skin. Brain Behav Immun. 2005;19:252-62.

63. Peters EM, Liezmann C, Spatz K, Daniltchenko M, Joachim R et al. Nerve growth factor partially recovers inflamed skin from stress-induced worsening in allergic inflammation. J Invest Dermatol. 2011;131:735-43.

64. Grip L, Lonne-Rahm SB, Holst M, Johansson B, Nordlind K, Theodorsson E et al. Substance $\mathrm{P}$ alterations in skin and brain of chronically stressed atopic-like mice. Eur Acad Dermatol Venereol. 2013;27:199-205.

65. Pavlovic S, Liezmann C, Blois SM, Joachim R, Kruse J, Romani N et al. Substance $P$ is a key mediator of stress-induced protection from allergic sensitization via modified antigen presentation. J Immunol. 2011;186:848-55

66. Stemmler S, Parwez Q, Petrasch-Parwez E, Epplen JT, Arinir U, Hoffjan S et al. Two common loss-of-function mutations within the filaggrin gene predispose for early onset of atopic dermatitis. J Invest Dermatol. 2007;127:722-4.

67. Kezic S, O'Regan GM, Yau N, Sandilands A, Chen H, Campbell LE et al. Levels of filaggrin degradation products are influenced by both filaggrin genotype and atopic dermatitis severity. Allergy. 2011;66:934-40.

68. Kezic S, O'Regan GM, Lutter R, Jakasa I, Koster ES, Saunderss S et al. Filaggrin loss-of-function mutations are associated with enhanced expression of IL-1 cytokines in the stratum corneum of patients with atopic dermatitis and in a murine model of filaggrin deficiency. J Allergy Clin Immunol. 2012;129:1031-9.

69. Voegeli R, Doppler S, Joller P, Breternitz M, Fluhr JW, Rawlings AV. Increased mass levels of certain serine proteases in the stratum corneum in acute eczematous atopic skin. Int J Cosmet Sci. 2011;33:560-5.

70. Kobayashi H, Kikuchi K, Tsubono Y, Tagami H. Measurement of electrical current perception threshold of sensory nerves for pruritus in atopic dermatitis patients and normal individuals with various degrees of mild damage to the stratum corneum. Dermatology. 2003;206:204-11.

71. Tominaga M, Ozawa S, Tengara S, Ogawa H, Takamori K. Intraepidermal nerve fibers increase in dry skin of acetone-treated mice. Dermatol Sci. 2007 Nov;48(2):103-11.

72. Kawasaki H, Nagao K, Kubo A, Hata T, Shimizu A, Mizuno H, Yamada T, Amagai M. Altered stratum corneum barrier and enhanced percutaneous immune responses in filaggrin-null miceJ Allergy Clin Immunol. 2012;129:1538-46.

73. Thyssen JP, Carlsen BC, Menné T. Linneberg A, Nielsen NH, Meldgaard M et al. Filaggrin null mutations increase th risk and persistence of hand eczema in subjects with atopic dermatitis: results from a general population study, BR J Dermattol. 2010;163:115-20.

74. Thyssen JP. The association between filaggrin mutations, hand eczema and contact dermatitis: a clear picture is emerging. Br J Dermatol. 2012;167:1197-8.

75. Nobbe S, Dziunycz P, Mühleisen B, Bilsborough J, Dillon SR, French LE et al. IL-31 expression by inflammatory cells is preferentially elevated in atopic dermatitis. Acta Derm Venereol. 2012;92:24-8.

76. Cornelissen C, Lüscher-Firzlaff J, Baron JM, Lüscher B. Signaling by IL-31 and functional consequences. Eur J Cell Biol. 2012;91:552-66.

77. Cornelissen C1, Marquardt $\mathrm{Y}$, Czaja K, Wenzel J, Frank J, Lüscher-Firzlaff J, Lüscher B, Baron JM. IL-31 regulates differentiation and filaggrin expression in human organotypic skin models. Allergy Clin Immunol. 2012;129:426-33.

78. Stott B, Lavender P, Lehmann S, Pennino D, Durham S, Schmidt-Weber CB. Human IL-31 is induced by IL-4 and promotes TH2-driven inflammation. Allergy Clin Immunol. $2013 ; 132: 446-54$.

79. Zhang Q1, Putheti P, Zhou Q, Liu Q, Gao W. Structures and biological functions of IL-31 and IL-31 receptors. Cytokine Growth Factor Rev. 2008;19:347-56.

80. Wong CK, Leung KM, Qiu HN, Chow JY, Choi AO, Lam CW. Activation of eosinophils interacting with dermal fibroblasts by pruritogenic cytokine IL-31 and alarmin IL-33: implications in atopic dermatitis. PLoS One. 2012;7:e29815.

81. Lee $\mathrm{CH}$, Hong $\mathrm{CH}$, Yu WT, Chuang HY, Huang SK, Chen GS et al. Mechanistic correlations between two itch biomarkers, cytokine interleukin-31 and neuropeptide $\beta$-endorphin, via STAT3/calcium axis in atopic dermatitis. $\mathrm{Br} \mathrm{J}$ Dermatol. 2012;167:794-803.

82. Kabashima K. New concept of the pathogenesis of atopic dermatitis: interplay among the barrier, allergy, and pruritus as a trinity. J Dermatol Sci. 2013;70:3-11.

83. Ezzat MH, Hasan ZE, Shaheen KY. Serum measurement of interleukin-31 (IL-31) in paediatric atopic dermatitis: elevated levels correlate with severity scoring. J Eur Acad Dermatol Venereol. 2011;25:334-9.

84. Kasraie S, Niebuhr M, Baumert K, Werfel T. Functional effects of interleukin 31 in human primary keratinocytes. Allergy. 2011;66:845-52.

85. Raap U, Weißmantel S, Gehring M, Eisenberg AM, Kapp A, Fölster-Holst R. IL-31 significantly correlates with disease activity and Th2 cytokine levels in children with atopic dermatitis. Pediatr Allergy Immunol. 2012;23:285.

86. Takaoka A, Arai I, Sugimoto M, Honma Y, Futaki N, Nakamura A, Nakaike S Involvement of IL-31 on scratching behavior in NC/Nga mice with atopic-like dermatitis. Exp Dermatol.2006;15:161-7.

87. Kasraie S, Niebuhr M, Werfel T. Interleukin (IL)-31 induces pro-inflammatory cytokines in human monocytes and macrophages following stimulation with staphylococcal exotoxins. Allergy. 2010;65:712-21

88. Grimstad O, Sawanobori Y, Vestergaard C, Bilsborough J, Olsen UB, GrønhøjLarsen $\mathrm{C}$, et al. Anti-interleukin-31-antibodies ameliorate scratching behaviour in NC/Nga mice: a model of atopic dermatitis. Exp Dermatol. 2009;18:35-43.

89. Cevikbas F, Wang X, Akiyama T, Kempkes C, Savinko T, Antal A, Kukova G, Buhl T, Ikoma A, Buddenkotte J, Soumelis V, Feld M, Alenius H, Dillon SR, Carstens E, Homey B, Basbaum A, Steinhoff M. A sensory neuron-expressed IL-31 receptor mediates Thelper cell-dependent itch: Involvement of TRPV1 and TRPA1. J Allergy Clin Immunol. 2014;133:448-460.

90. Na SY, Roh JY, Kim JM, Tamang MD, Lee JR. Analysis of Colonization and Genotyping of the Exotoxins of Staphylococcus aureus in Patients with Atopic Dermatitis. Ann Dermatol. 2012;24:413-9.

91. Lee HW, Kim SM, Kim JM, Oh BM, Kim JY, Jung HJ et AL. Potential Immunoinflammatory Role of Staphylococcal Enterotoxin $A$ in Atopic Dermatitis: Immunohistopathological Analysis and in vitro Assay. Ann Dermatol. 2013;25:173-80.

92. Lin YT, Wang CT, Chiang BL. Role of bacterial pathogens in atopic dermatitis. Clin Rev Allergy Immunol. 2007;33:167-77.

93. Niebuhr M, Mamerow D, Heratizadeh A, Satzger I, Werfel T. Staphylococcal $\alpha$-toxin induces a higher T cell proliferation and interleukin-31 in atopic dermatitis. Int Arch Allergy Immunol. 2011;156:412-5.

94. Kasraie S, Niebuhr M, Kopfnagel V, Dittrich-Breiholz O, Kracht M, Werfel T. Macrophages from patients with atopic dermatitis show a reduced CXCL10 expression in response to staphylococcal $\alpha$-toxin. Allergy. 2012;67:41-9.

95. Ohshima M, Miyake M, Takeda M, Kamijima M, Sakamoto T. Staphylococcal enterotoxin B causes proliferation of sensory C-fibers and subsequent enhancement of neurogenic inflammation in rat skin. J Infect Dis. 2011;203:862-9.

96. Bexley J, Nuttall TJ, Hammerberg B, Fitzgerald JR, Halliwell RE. Serum antiStaphylococcus seudintermedius $\lg \mathrm{E}$ and $\lg \mathrm{G}$ antibodies in dogs with atopic dermatitis. Vet Dermatol. 2013; 24:19-94.

97. Zheng J. Molecular Mechanism of TRP Channels . Compr Physiol. 2013;3:221 42.

98. Montell C. The history of TRP channels, a commentary and reflection. Pflugers Arch. 2011:461:499-506

99. Dubé J, Rochette-Drouin 0, Lévesque P, Gauvin R, Roberge CJ. Human keratinocytes respond to direct current stimulation by increasing intracellular calcium: preferential response of poorly differentiated cells. J Cell Physiol. 2012;227:2660-7.

100. Sweeney ZK, Minatti A, Button DC, Patrick S. Small-molecule inhibitors of storeoperates calcium entry. Chem Med Chem. 2009;4:706-18.

101. Denda M, Tsutsumi M. Roles of transient receptor potential proteins (TRPs) epidermal keratinocytes. Adv Exp Med Biol. 2011; 704:847-60.

102. Steinhoff M, Bíró T. A TR(I)P to pruritus research: role of TRPV3 in inflammation and itch. J Invest Dermatol. 2009;129:531-5.

103. Tang HB, Li YS, Miyano K, Nakata Y. Phosphorylation of TRPV1 by neurokinin-1 receptor agonist exaggerates the capsaicin-mediated substance $P$ release from 
cultured rat dorsal root ganglion neurons. Neuropharmacology. 2008;55:1405-11.

104. Velázquez RA1, McCarson KE, Cai Y, Kovács KJ, Shi Q, Evensjö M, Larson AA. Upregulation of neurokinin-1 receptor expression in rat spinal cord by an N-terminal metabolite of substance P. Eur J Neurosci. 2002 ;16:229-41.

105. Denda M, Sokabe T, Fukuni-tominaga T, Tominaga M. Effects of skin surface temperature on the epidermal permeability barrier homeostasis. J Invest Dermatol. 2007:127:654-9.

106. Munaron L. Intracellular calcium, endothelial cells and angiogenesis. Recent Pat Anticancer Drug Discov. $2006 ; 1: 105-19$.

107. Antoniotti S, Fiorio Pla A, Barral S, Scalabrino O, Munaron L, Lovisolo D. Interaction between TRPC channel subunits in endothelial cells. J Recept Signal Transduct Res. 2006;26:225-40.

108. Cioffi DL. Redox regulation of endothelial canonical transient receptor potential channels. Antioxid Redox Signal. 2011 Sep 15;15:1567-82.

109. Imamachi N1, Park GH, Lee H, Anderson DJ, Simon MI, Basbaum Al, Han SK TRPV1-expressing primary afferents generate behavioral responses to pruritogens via multiple mechanisms. Proc Natl Acad Sci U S A. 2009;106:11330-5.

110. Müller M, Essin K, Hill K, Beschmann H, Schempp CM, Gollasch M et al. Specific TRPC6 channel activation, a novel approach to stimulate keratinocyte differentiation. . J Biol Chem. 2008:283:33942:54.

111. Cai S, Fatherazi S, Presland RB, Belton CM, Izutzu KT. TRPC channel expression during calcium induction differentiation of human gingival keratinocytes. $J$ Dermatol Sci. 2005;40:21-8.

112. Sun XD, You Y, Zhang L, Zheng S, Hong Y, Li J et al.The possible role of TRPC6 in atopic dermatitis. Med Hypotheses. 2012;78:42-4.

113. Boehncke WH, Harteneck C, Müller WE, Leuner K. Specific TRPC6 channel activation, a novel approach to stimulate keratinocyte differentiation. J Biol Chem. 2008;283:33942-54.

114. Amagai Y, Matsuda H, Tanaka A. Abnormalities in Itch Sensation and Skin Barrier Function in Atopic NC/Tnd Mice. Biol Pharm Bull. 2013;36:1248-52.

115. Yun JW, Seo JA, Jeong YS, Bae IH, Jang WH, Lee J et al. TRPV1 antagonist can suppress the atopic dermatitis-like symptoms by accelerating skin barrier recovery. J Dermatol Sci. 2011;62:8-15.

116. Yun JW, Seo JA, Jang WH, Koh HJ, Bae IH, Park YH, Lim KM. Antipruritic effects of TRPV1 antagonist in murine atopic dermatitis and itching models. J Invest Dermatol. 2011;131:1576-9.1

117. Lim KM, Park YH. Development of PAC-14028, a novel transient receptor potential vanilloid type 1 (TRPV1) channel antagonist as a new drug for refractory skin diseases. Arch Pharm Res. 2012;35:393-6.

118. Tu CL, Bikle DD. Role of the calcium-sensing receptor in calcium regulation of epidermal differentiation and function. Best Pract Res Clin Endocrinol Metab. 2013;27:415-27.

119. Ray JM, Squires PE, Meloche RM, Nelson DW, Smith TP, Buchan AM et al. L Type calcium channels regulate gastrin release from human $\mathrm{G}$ cells. Am J Puysiol 1997;273:62281-8

120. Heffner KL, Kiecolt-Glaser JK, Glaser R, Malarkey WB, Marshall GD. Stress and anxiety effects on positive skin test responses in young adults with allergic rhinitis. Ann Allergy Asthma Immunol. 2014;113:13-8.
MAILING ADDRESS:

Neide Kalil Gaspar

Mariz e Barros St., 297

Icaraí

24220-120 - Niterói, RJ

Brazil

Email: neide2605@yahoo.com.br

How to cite this article: Kalil-Gaspar N, Aidé MK. Atopic dermatitis: allergic dermatitis or neuroimmune dermatitis? An Bras Dermatol. 2016;91(4):479-88. 